\section{Factors associated with the diffusion rate of innovations: a pilot study from the perspective of the Brazilian Unified National Health System}

\author{
Fatores associados à taxa de difusão das \\ inovações: um estudo piloto desde a perspectiva \\ do Sistema Único de Saúde
}

\author{
Factores asociados con la tasa de difusión \\ de innovaciones: un estudio piloto desde la \\ perspectiva del Sistema Único de Salud brasileño
}

Roberto Eduardo Schneiders 1 Ricardo de March Ronsoni 1 Flávia Mori Sarti 2 Marcelo Eidi Nita 3 Ediane de Assis Bastos 1 Ivan Ricardo Zimmermann 4 Fernando Fagundes Ferreira 2

\begin{abstract}
Budget impact analyses require a set of essential information on health technology innovation, including expected rates of adoption. There is an absence of studies investigating trends, magnitude of budgetary effects and determinants of diffusion rates for health technology innovations worldwide during the last decades. The present study proposes a pilot assessment on main determinants influencing diffusion rates of pharmaceutical innovations within the Brazilian Unified National Health System (SUS). Data from the Brazilian Health Informatics Department (DATASUS) was gathered to establish the main determinants of diffusion rates of health technology innovations in Brazil, specifically referring to pharmaceutical innovations incorporated in the Brazilian Program for Specialized Pharmaceutical Services (CEAF) at SUS. Information was retrieved on DATASUS relating to patients who had used one of the medicines incorporated into CEAF at least three years prior to the beginning of the study (2015) for treatment of each health condition available. Thus, data from patients adopting 10 different medicines were analyzed in the study. Results from the zero-one inflated beta model showed a higher influence on diffusion rates of pharmaceutical innovations due to: number of pharmaceutical competitors for treatment of the same disease available at CEAF (negative); medicine used in combination with other medication (positive); and innovative medicine within the SUS (positive). Further research on diffusion rates of health technology innovations is required, including wider scope of diseases and medications, potential confusion factors and other variables that may influence rates of adoption in different health systems.
\end{abstract}

Diffusion of Innovation; Biomedical Technology Assessment; Health Evaluation

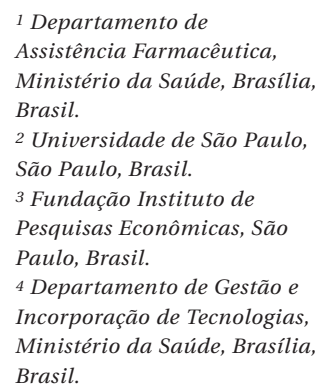

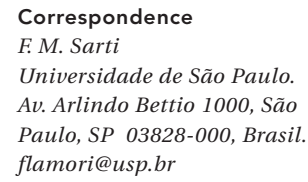




\section{Introduction}

The objectives of the Brazilian Unified National Health System (SUS) include assurance of universal health care coverage and integral health assistance within a publicly financed health structure. Nevertheless, recent demographic and epidemiologic trends in Brazil, along with rapid developments of technological innovations, have been posing challenges to health system management. Numerous technical alternatives available for adoption in health care have been producing continuous increases of health expenditures 1 .

Policies towards health technology assessment may support rational incorporation of innovations in national health systems to guarantee economic sustainability. In 2011, the National Committee for Health Technology Incorporation (CONITEC) was established to support the Brazilian Ministry of Health on decisionmaking processes related to health technology assessments and the incorporation of therapeutic innovations ${ }^{2}$.

CONITEC is responsible for issuing recommendations on health innovations to be incorporated, excluded or modified within the SUS, supported by scientific evidence on efficacy, accuracy, effectiveness, safety and costs; including economic evaluation and budget impact analysis (BIA), from the SUS perspective ${ }^{3}$. There has been growing interest in BIA recently ${ }^{4}$ and Health Technology Assessment (HTA) agencies in several countries request BIA to support decision making processes on the adoption of health technology innovations 5,6,7,8.

Economic evaluation studies provide useful information on the adoption of innovations; however, their results lack information on potential economic impacts on national health accounts. BIA results include the projection of expenditures due to the incorporation of health technology innovations for diagnosis and treatment of populations during specific periods, based on a comparison of alternative scenarios, using payer perspectives 1,9,10.

Yet, in order to perform BIA, essential information on health technology implementation is required: prices, prescription, and adoption rates. Estimates of adoption rates in health systems are usually based on studies of diffusion rates of technological innovations; which are influenced by population characteristics, including communication among individuals (e.g., prescription, marketing, or patients' requests) and predisposition for technology adoption (e.g., physicians' or patients' preferences for innovation); however, there are controversies regarding the magnitude of effect from diverse variables $5,11,12,13,14,15,16$. Consequently, information to perform BIA is usually based on market-specific evidence or experts' consultations.

Delay in technology adoption after incorporation to the health system may occur due to differences in personal characteristics among diverse health professionals and patients (e.g. resistance in acceptance of innovations, or lack of information), changing budget impacts over time; thus, diffusion rates of health innovations are crucial for BIA 4 .

This study proposes an innovative approach to identifying factors influencing diffusion rates of medicines incorporated within the SUS, in order to provide evidence to support further advances in health technology assessment.

\section{Methods}

Detailed data from the Ambulatory Information System (SIA) of the Brazilian Health Informatics Department (DATASUS) was gathered to establish determinants of diffusion rates of health technology innovations in Brazil, specifically referring to pharmaceutical innovations incorporated in the Brazilian Program for Specialized Pharmaceutical Services (CEAF). This option was selected on account of the availability of information on patients using numerous types of medication for treatment of diverse health conditions, available online within the DATASUS platform using TabWin software (DATASUS. http://portal. saude.gov.br/portal/se/datasus/area.cfm?id_ area=732).

CEAF databases encompassed nationwide information on pharmaceutical services, reported by Brazilian states to the Ministry of Health, referring to every event of medication distribution for each patient (identified using the cryptographic number from the National Health Card), diagnosis, and medication characteristics. Data available from any patients using any medicines incorporated into CEAF at least three years before the beginning of this study (2015) for treatment of any health condition was included in the analysis, ensuing data from patients adopting 10 medicines (Table 1).

Considering evidence from the literature 15,16, a dataset containing 17 categories of variables potentially associated with adoption rates of medication within the SUS was generated, including variables related to characteristics of diseases, respective medications and its prices, treatment protocols and costs (Table 2).

Diffusion rates were based on the percentage of patients using medication among patients 
Table 1

Selected pharmaceutical innovations incorporated in the Brazilian Program for Specialized Pharmaceutical Services (CEAF). Brazil, 2015.

\begin{tabular}{|c|c|c|c|c|c|c|c|}
\hline \multirow[t]{3}{*}{ Medicine } & \multirow[t]{3}{*}{$\begin{array}{l}\text { Incorporation } \\
\text { date }\end{array}$} & \multirow[t]{3}{*}{ Indication } & \multirow[t]{3}{*}{$\begin{array}{l}\text { Other treatments } \\
\text { available at CEAF }\end{array}$} & \multicolumn{4}{|c|}{$\begin{array}{l}\text { Proportion of patients using innovative medicine * } \\
\text { [month/period] (\%) }\end{array}$} \\
\hline & & & & $1^{\text {st }}$ & $12^{\text {th }}$ & 24th & $36^{\text {th }}$ \\
\hline & & & & $t=0$ & $t=4$ & $t=8$ & $t=12$ \\
\hline Cyclophosphamide & Oct/2008 & $\begin{array}{l}\text { Acquired chronic } \\
\text { pure red cell aplasia }\end{array}$ & $\begin{array}{l}\text { Azathioprine, } \\
\text { Cyclosporine, } \\
\text { Immunoglubulin }\end{array}$ & 0.0 & & & \\
\hline Deferasirox & Oct/2008 & $\begin{array}{l}\text { Chronic iron } \\
\text { overload }\end{array}$ & $\begin{array}{l}\text { Deferiprone, } \\
\text { Deferoxamine }\end{array}$ & 0.0 & 67.5 & 76.9 & 79.6 \\
\hline Everolimus & Oct/2008 & Kidney transplant & $\begin{array}{c}\text { Azathioprine, } \\
\text { Cyclosporine, } \\
\text { Methylprednisolone, } \\
\text { Mycophenolate } \\
\text { mofetil, } \\
\text { Mycophenolate } \\
\text { sodium, Sirolimus, } \\
\text { Tacrolimus }\end{array}$ & 0.0 & 0.1 & 1.2 & 1.9 \\
\hline Galantamine & Oct/2008 & Alzheimer's disease & $\begin{array}{l}\text { Donepezil, } \\
\text { Rivastigmine }\end{array}$ & 7.4 & 11.7 & 15.5 & 16.8 \\
\hline $\begin{array}{l}\text { Aluminium } \\
\text { hydroxide }\end{array}$ & Mar/2010 & $\begin{array}{l}\text { Hyperphosphatemia } \\
\text { in chronic kidney } \\
\text { insufficiency }\end{array}$ & Calcitriol, Sevelamer & 0.0 & 0.0 & 0.0 & 0.0 \\
\hline Clobazam & Mar/2010 & Epilepsy & $\begin{array}{c}\text { Ethosuximide, } \\
\text { Gabapentin, } \\
\text { Lamotrigine, } \\
\text { Primidone, } \\
\text { Topiramate, } \\
\text { Vigabatrin }\end{array}$ & 0.0 & 5.1 & 3.7 & 4.5 \\
\hline Entecavir & $\mathrm{Dec} / 2009$ & Hepatitis B & $\begin{array}{c}\text { Adefovir, Interferon- } \\
\text { alpha, Lamivudine, } \\
\text { Tenofovir }\end{array}$ & 0.0 & 21.8 & 30.0 & \\
\hline Sildenafil & Mar/2010 & $\begin{array}{l}\text { Pulmonary arterial } \\
\text { hypertension }\end{array}$ & Iloprost & 99.0 & 99.9 & 99.9 & 100.0 \\
\hline Natalizumab & Mar/2010 & Multiple sclerosis & $\begin{array}{l}\text { Azathioprine, } \\
\text { Glatiramer, } \\
\text { Interferon-beta }\end{array}$ & 0.0 & 2.0 & 5.2 & 6.6 \\
\hline Pyridostigmine & Mar/2010 & Myasthenia gravis & $\begin{array}{l}\text { Azathioprione, } \\
\text { Cyclosporine, } \\
\text { Immunoglobulin }\end{array}$ & 0.0 & 27.2 & 32.8 & 36.6 \\
\hline
\end{tabular}

* Percentage in relation to the total number of patients treated for the disease at the CEAF for the same use.

Source: prepared by the authors, based on synthesis from Brazilian Health Informatics Department (DATASUS).

diagnosed with disease, considering the 10th revision of the International Classification of Diseases (ICD-10), according to region, state and lag period after incorporation (trimester from incorporation until last period available). Zeroone inflated beta model was estimated to identify factors influencing the diffusion rate of pharmaceutical innovations in the SUS 17 using R soft- ware (The R Foundation for Statistical Computing, Vienna, Austria; http://www.r-project.org). 
Table 2

Description and characterization of categories of independent variables for analysis of diffusion rate of pharmaceutical innovations in the Brazilian Unified National Health System (SUS). Brazil, 2015.

\begin{tabular}{|c|c|c|}
\hline \multicolumn{2}{|c|}{ Category of variable } & Value \\
\hline \multicolumn{2}{|c|}{ 1. Other treatments already available at the CEAF } & Binary variable \\
\hline \multirow[t]{2}{*}{ Description } & $\begin{array}{l}\text { Analyzes the influence of preexistence of other medication available for treatment of the same } \\
\text { disease at CEAF, which may facilitate access to pharmaceutical innovations due to previous }\end{array}$ & (Yes, No) \\
\hline & knowledge of physicians and patients. & \\
\hline Method & $\begin{array}{l}\text { Search in CEAF ordinances to identify other medication associated with ICD-10 correspondent to } \\
\text { the specific disease targeted by the pharmaceutical innovation. }\end{array}$ & \\
\hline \multicolumn{2}{|c|}{ 2. Number of competitors for treatment of the same disease } & Discrete variable \\
\hline Description & $\begin{array}{l}\text { Identifies the amount of competitor medications for the same line of treatment of the disease, } \\
\text { influencing the probability of pharmaceutical innovation adoption. }\end{array}$ & (Count) \\
\hline Method & $\begin{array}{l}\text { Analysis of the first clinical PCDT available for the targeted disease. If no competitor medications } \\
\text { are mentioned, the variable value was zero. Otherwise, the number of active principles competing } \\
\text { for treatment of the same disease was computed. }\end{array}$ & \\
\hline \multicolumn{2}{|c|}{ 3. Line of treatment } & Binary variable for each line of \\
\hline Description & $\begin{array}{l}\text { Analyzes the influence of the line of treatment on diffusion rates, since medication in the last line of } \\
\text { treatment, theoretically, should be prescribed to a smaller number of patients. }\end{array}$ & $\begin{array}{l}\text { treatment } \\
\text { (1st line, 2nd line, 3rd line, or }\end{array}$ \\
\hline \multirow[t]{2}{*}{ Method } & $\begin{array}{l}\text { Analysis of the first PCDT available for the targeted disease, in order to identify changes in line of } \\
\text { treatment using another health technology (pharmaceutical or other) in case of refractoriness, fail } \\
\text { or intolerance to standard treatment. If it was not possible to establish a line of treatment, the term }\end{array}$ & NA) \\
\hline & "non-defined" was attributed. & \\
\hline \multicolumn{2}{|c|}{ 4. Medicine used in combination with other medication } & Binary variable \\
\hline Description & $\begin{array}{l}\text { Verifies the influence of need to adopt a combined use of medication, due to potential difficulties } \\
\text { to access other medicines prescribed. }\end{array}$ & (Yes, No) \\
\hline Method & $\begin{array}{l}\text { Analysis of the first PCDT available for the targeted disease, in order to identify indication of use in } \\
\qquad \text { association with other medicines. }\end{array}$ & \\
\hline \multicolumn{2}{|c|}{ 5. Innovation within the SUS } & Binary variable \\
\hline Description & $\begin{array}{l}\text { Analyzes the influence of incremental benefits of the pharmaceutical innovation in comparison to } \\
\text { other types of treatment of the disease. }\end{array}$ & (Yes, No) \\
\hline \multirow[t]{6}{*}{ Method } & $\begin{array}{l}\text { Due to absence of specific definition regarding the concept of innovation in health care, the } \\
\text { following premises were adopted: }\end{array}$ & \\
\hline & Medication for treatment of diseases not yet available at SUS; & \\
\hline & Medication for treatment of diseases already available that: & \\
\hline & Represents new line of treatment of the disease; or & \\
\hline & $\begin{array}{l}\text { Presents improved efficacy in relation to other medication already available, based on search of } \\
\text { evidences published in meta-analysis or direct comparison } 20,21 .\end{array}$ & \\
\hline & $\begin{array}{l}\text { Other medications competing in the same line of treatment and in the same pharmacological } \\
\text { category were not considered innovative. }\end{array}$ & \\
\hline \multicolumn{2}{|c|}{ 6. Time gap between from incorporation and clinical protocol publication (months) } & Discrete variable \\
\hline Description & $\begin{array}{c}\text { Analyzes the influence of PCDT in diffusion rates, due to definition of prescription and utilization } \\
\text { criteria. }\end{array}$ & (Count) \\
\hline Method & $\begin{array}{l}\text { Identification of the publication date of PCDT. If the PCDT was published prior to the medication } \\
\text { incorporation, the variable value was zero. }\end{array}$ & \\
\hline \multicolumn{2}{|c|}{ 7. Treatment for infectious diseases } & Binary variable \\
\hline Description & $\begin{array}{l}\text { Analyzes the influence of type of disease in diffusion rates of pharmaceutical innovations, } \\
\text { considering that infectious diseases have limited time for treatment in comparison to other types } \\
\text { of diseases. }\end{array}$ & (Yes, No) \\
\hline Method & Assessment of characteristics of the targeted diseases, according to description in PCDT. & \\
\hline
\end{tabular}

(continues) 
Table 2 (continued)

Category of variable

Value

8. Lag period after incorporation of the medicine (in trimesters)

Description Information used to estimate the diffusion rates over time (up to three years after incorporation).

Method Assignment of ordinal category corresponding to the number of trimesters after incorporation.

\section{Area of specialty in medicine}

Description Analyzes the influence of the area of medical specialty of the disease on diffusion rates of pharmaceutical innovations.

Method Analysis of the PCDT for the targeted disease, in order to determine the area of medical specialty for treatment of the disease. Each disease was categorized in only one specialist area, if more than one area was indicated; the most representative specialist area was adopted.

10. Medicine with patent (monopoly)

Description Analyzes the influence of the presence or absence of generic or similar drugs at the moment of incorporation, which presupposes the absence or presence of patent, respectively.

Method Search in the price list of the Chamber for Regulation of the Pharmaceutical Market, in order to identify generic or similar drugs in Brazil.

\section{Annual cost of drug therapy per patient}

Description Analyzes the interference of drug therapy costs per patient in the diffusion rate and potential impacts of reduction in prices due to scale in production, considering that overall budget impact may influence the access to medication within the SUS.

Method

Estimation of annual costs for standard treatment (in log), considering recommended dosage of the medication in the PCDT for the targeted disease, at the period of pharmaceutical innovation incorporation within the SUS. A standard patient profile weighting $70 \mathrm{~kg}$ was adopted, in case of dosage per body weight. The annual costs were based on the amount of medication for annual treatment and the PMC (18\%) from the Chamber for Regulation of the Pharmaceutical Market (2014).

12. Higher price in comparison to pharmaceutical competitors

Description Analyzes the influence of variations in price on the diffusion rate, in comparison with other technologies for drug therapy of the same disease already available at the SUS.

Method Comparison of the variable "annual cost of drug therapy per patient" in relation to the annual costs estimated for drug therapy of the targeted disease using other medication available within SUS. The annual costs were based on the amount of medication for annual treatment and the PMC (18\%) from the Chamber for Regulation of the Pharmaceutical Market (2014). If there are no other therapeutic options for treatment of the disease, the variable value was "non applicable".

13. Public management level responsible for acquisition of medication

Description Assesses the impact of diverse patterns of acquisition of medication for CEAF (federal, and/or state level acquisition) on diffusion rates.

Method Identification of the public management level responsible for acquisition of the medication, through search in Ministry of Health ordinances that established the Component of Medications with Exceptional Dispensation (Ordinance GM/MS 2,577/2006), the CEAF (Ordinance GM/ MS 2,981/2009), and other ordinances published for alteration or revocation of the previous ordinances and its annexes. Changes in responsibility during the period analyzed were categorized as "both".

\section{State of residence of patient}

Description Verifies differences among states of residence of patients in the access of medication provided by SUS or in execution of CEAF, and its influence on diffusion rates.

Method Extraction of data regarding patients' state of residence from SUS databases, described in Methods.

(continues) 


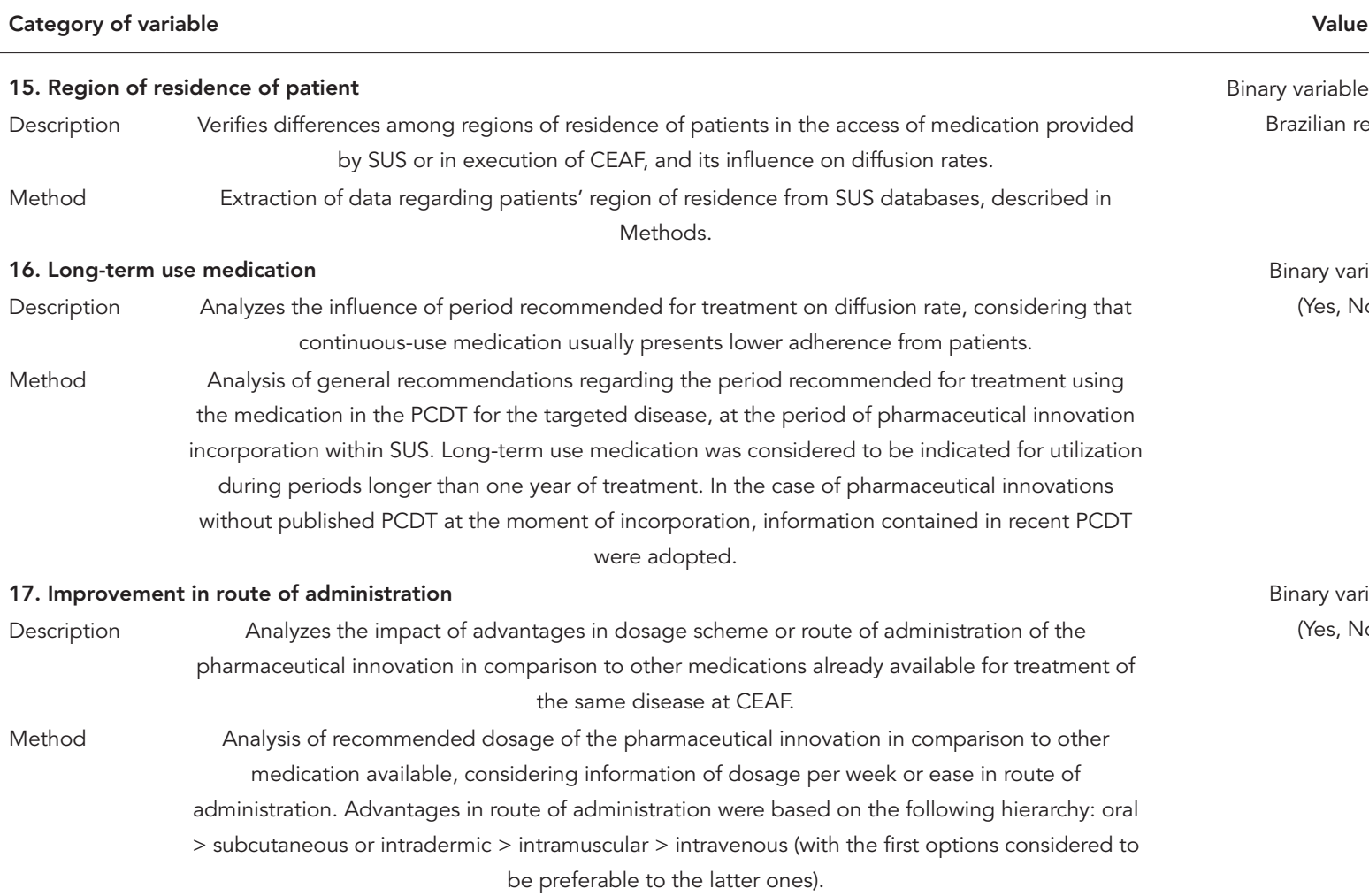

Binary variable: variable assuming values 0 or 1 , according to the characteristics attributable to the case in analysis, indicating the effect of the characteristic described on the rate of adoption; CEAF: Brazilian Program for Specialized Pharmaceutical Services; ICD-10: 10th revision of the International Classification of Diseases; NA: non-applicable; PCDT: clinical protocol and therapeutic guideline; PMC: maximum price for consumers. Source: prepared by the authors, based on synthesis of documental research at the Brazilian Ministry of Health.

\section{Results}

Considering 17 categories of independent variables described, seven categories presented association with diffusion rates (Table 3 ).

Results from the zero-one inflated beta model showed a higher influence on diffusion rates of pharmaceutical innovations due to: the number of pharmaceutical competitors for treatment of disease available at CEAF (negative); medicine used in association (positive); and innovative medicine within the SUS (positive).

Variables related to the characteristics of pharmaceutical innovations were prominent to diffusion rates within the SUS, whereas organizational characteristics of the health system adopting innovations were mostly represented by region of residence of patients, which may account for major differences in infrastructure and management of the SUS.

There was a set of variables without a statistically significant association with diffusion of pharmaceutical innovations within the SUS: other treatments available at CEAF; line of treatment; time gap to clinical protocol publication; type of disease and medical specialty; patent; price in comparison to competitors; management level responsible for acquisition; patients' state of residence; and route of administration. Nevertheless, considering the correlation between variables excluded and some variables included in the model, it was expected that part of the variables tested would be omitted.

\section{Discussion}

There is a lack of evidence in the scientific literature regarding theoretical frameworks and methods to support BIA referring to adoption rates of health technology innovations within national health systems, either in the public or private sectors. A limited number of studies investigated trends of budgetary effects and determinants of diffusion rates of recent health technology innovations worldwide. This study proposes a pilot assessment on determinants influencing 
Coefficients of zero-one inflated beta model for diffusion rate of pharmaceutical innovations in the Brazilian Unified National Health System (SUS). Brazil, 2015.

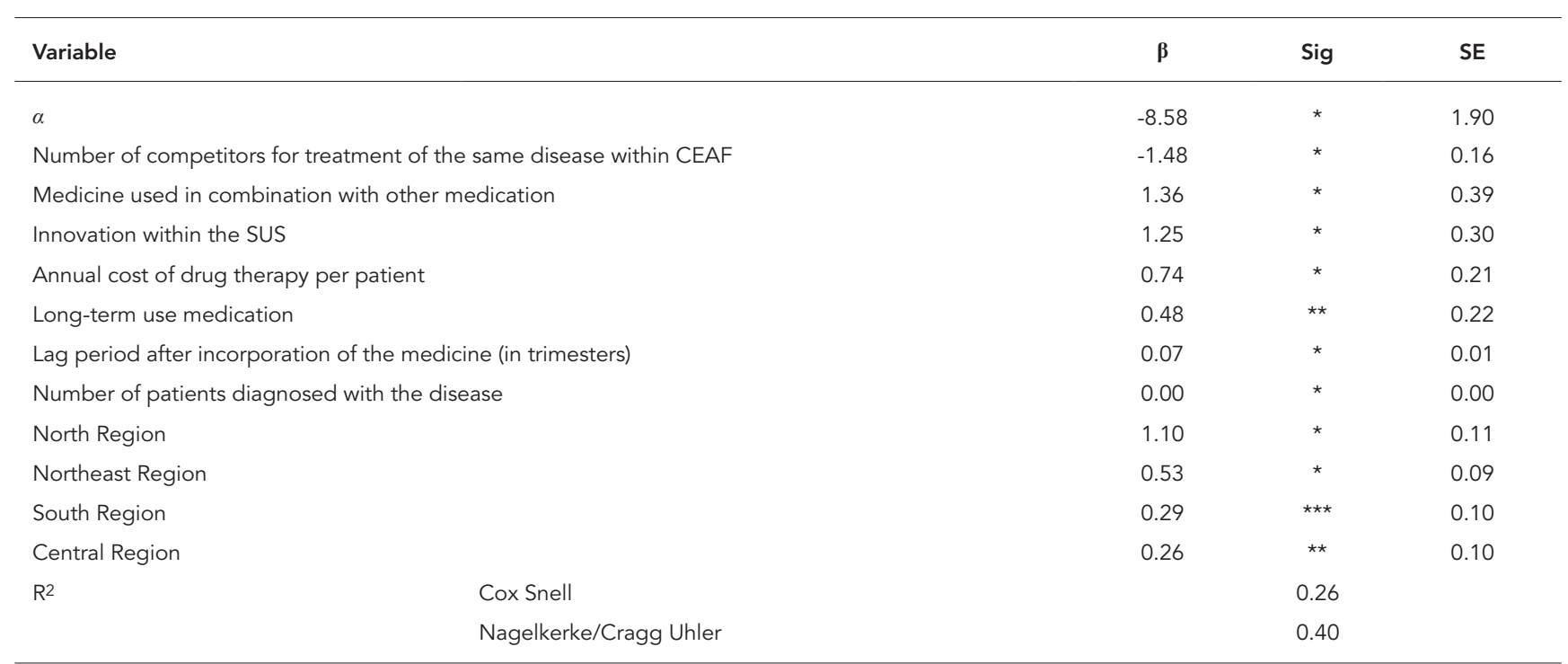

${ }^{*} p<0.001 ;$

$\star * p<0.05$

$\star * \star p<0.01$

$\alpha$ : intercept; $\beta$ : coefficient of the corresponding variable in regression results; CEAF: Brazilian Program for Specialized Pharmaceutical Services; SE: standard error of the corresponding variable; Sig: statistical significance of the coefficient of the corresponding variable in the model.

Categories of variables presenting association with the diffusion rates = number of competitors for treatment of the same disease within CEAF; Medicine used in combination with other medication; Innovation within the SUS; Annual cost of drug therapy per patient; Long-term use medication; Lag period after incorporation of the medicine (in trimesters); and Region of residence of the patient.

diffusion rates of pharmaceutical innovations within the SUS.

Results obtained were consistent with prior knowledge on diffusion rates of novel medication 15,16 , showing trends for faster diffusion rates of medication with incremental benefits, and treatments with higher costs inducing higher demand within the SUS. Slower adoption rates of medication with substitutes (competitors) within CEAF indicated impact on prices due to competition in the pharmaceutical market.

This study investigated influences on the rate of diffusion of pharmaceutical innovations within the SUS on two of three possible dimensions 15: medication features and organizational characteristics. The third dimension, regarding characteristics of individuals, was not within the scope of databases used to perform the analyses; thus, a main limitation of the study is the lack of information on the preferences of physicians, patients, society and the pharmaceutical industry.

Another limitation is the potential duplication of patients' records within DATASUS data- bases; considering evidence showing that quality of data extracted from DATASUS may be compromised due to duplication or lack of consistency in the patients' registry, depending on the type of information used 18,19. Nevertheless, with regard to the CEAF data, limitations are considerably lower, due to the need of medical prescriptions for treatment of each patient diagnosed within the SUS during the same period (monthly).

Contributions made by this pilot study in measuring diffusion rates of pharmaceutical innovations and identifying their immediate determinants should be acknowledged due to internal validity of analysis and viability for reproduction to support further evidence for BIA research.

In order to ensure the external validity of results obtained in this study, further research on diffusion rates of health technology innovations is required, including a wider scope of diseases and medication, potential confusion factors and other variables that may influence rates of adoption in different health systems. 


\section{Contributors}

R. E. Schneiders, R. M. Ronsoni, F. M. Sarti, M. E. Nita E. A. Bastos and I. R. Zimmermann contributed in the conception and design, article write-up and critical revision, approval of final version for publication, and responsibility for all elements of the study in its entirety ensuring accuracy and integrity. F. F. Ferreira collaborated in the data analysis and interpretation, article write-up and critical revision, approval of final version for publication, and responsibility for all elements of the study in its entirety ensuring accuracy and integrity.

\section{Acknowledgments}

The authors wish to thank Dr. Jerzy Wieczorek for providing further information on his paper Bayesian ZeroOne Inflated Beta Model for Estimating Poverty in U.S Counties and also the reviewers for their suggestions while evaluating the article

\section{References}

1. Ministério da Saúde. Diretrizes metodológicas. Estudos de avaliação econômica de tecnologias em saúde. Brasília: Ministério da Saúde; 2009. (Série A. Normas e Manuais Técnicos).

2. Ministério da Saúde. Política Nacional de Gestão de Tecnologias em Saúde. Brasília: Ministério da Saúde; 2010. (Série B. Textos Básicos em Saúde).

3. Laranjeira FO, Petramale CA. A avaliação econômica em saúde na tomada de decisão: a experiência da CONITEC. BIS Boletim do Instituto Saúde 2013; 14:165-70.
4. Garay O, Caporale J, Pichón-Riviere A, Martí S, Mullen M, Augustovski F. El análisis de impacto presupuestario en salud: puesta al día con un modelo de abordaje genérico. Rev Peru Med Exper Salud Pública 2011; 28:540-7.

5. Cohen JP, Stolk E, Niezen M. Role of budget impact in drug reimbursement decisions. J Health Polit Policy Law 2008; 33:225-47. 
6. Garattini L, van de Vooren K. Budget impact analysis in economic evaluation: a proposal for a clearer definition. Eur J Health Econ 2011; 12:499-502.

7. Niezen MGH, de Bont A, Busschbach JJ, Cohen JP, Stolk EA. Finding legitimacy for the role of budget impact in drug reimbursement decisions. Int J Techn Assess Health Care 2009; 25:49-55.

8. Mauskopf JA, Earnshaw S, Mullins CD. Budget impact analysis: review of the state of the art. Expert Rev Pharmacoecon Outcomes Res 2005; 5:65-79.

9. Ministério da Saúde. Diretrizes metodológicas. Análise de impacto orçamentário: manual para o Sistema de Saúde do Brasil. Brasília: Ministério da Saúde; 2012. (Série A. Normas e Manuais Técnicos).

10. Ferreira-da-Silva AL, Ribeiro RA, Santos VCC, Elias FTS, d'Oliveira ALP, Polanczyk CA. Diretriz para análises de impacto orçamentário de tecnologias em saúde no Brasil. Cad Saúde Pública 2012; 28:1223-38.

11. Martins ACR, Pereira CB, Vicente R. An opinion dynamics model for the diffusion of innovations. Physica A 2009; 338:3225-32.

12. Orlewska E, Gula L. Budget-impact analyses: a critical review of published studies. Pharmacoeconomics 2009; 27:807-27.

13. Marshall DA, Douglas PR, Drummond MF, Torrance GW, Macleod S, Manti O, et al. Guidelines for conducting pharmaceutical budget impact analyses for submission to public drug plans in Canada. Pharmacoeconomics 2008; 26:477-95.

14. Lerner JC, Robertson DC, Goldstein SM. Improve accuracy case studies on forecasting for innovative technologies: frequent revisions. Health Aff 2015; 34:311-8.
15. Berwick DM. Disseminating innovations in health care. JAMA 2003; 289:1969-75.

16. Sanson-Fisher RW. Diffusion of innovation theory for clinical change. Med J Aust 2004; 180 (6 Suppl):S55-6.

17. Cribari-Neto F, Zeileis A. Beta regression in R. Research report series - WU Vienna. http://epub. wu.ac.at/726/1/document.pdf (accessed on 27/ Jun/2016).

18. Brandão CM, Guerra AA, Cherchiglia ML, Andrade EI, Almeida AM, Silva GD, et al. Gastos do Ministério da Saúde do Brasil com medicamentos de alto custo: uma análise centrada no paciente. Value Health 2011; 14(5 Suppl 1):S71-7.

19. Cherchiglia ML, Machado CJ, Andrade EIG, Acurcio FA, Szuster DAC, Guerra Junior AA, et al. O uso de sistema de informação do Sistema Único de Saúde na análise de desfecho: limites e perspectivas. In: Nita ME, Campino ACC, Secoli SR, Sarti FM, Nobre MRC, Costa AMN, et al. organizadores. Avaliação de tecnologias em saúde: evidência clínica, análise econômica e análise de decisão. Porto Alegre: Editora Artmed; 2010. p. 116-27.

20. Cramer JA, Sapin C, Francois C. Indirect comparison of clobazam and other therapies for Lennox-Gastaut syndrome. Acta Neurol Scand 2013; 128:91-9.

21. Maggio A, Filosa A, Aloj G, Kattamis A, Ceci A, Fucharoen S, et al. Iron chelation therapy in thalassemia major: a systematic review with metaanalyses of 1520 patients included on randomized clinical trials. Blood Cells Mol Dis 2011; 47:166-75. 


\section{Resumo}

As análises de impacto orçamentário exigem um conjunto de informações essenciais sobre inovação em tecnologias da saúde, inclusive taxas esperadas de adoção. Nas últimas décadas, verifica-se ausência de estudos internacionais sobre tendência, tamanho do impacto orçamentário e determinantes das taxas de difusão das inovações tecnológicas em saúde. O estudo propõe uma avaliação preliminar dos principais determinantes das taxas de difusão de inovações tecnológicas no Sistema Único de Saúde (SUS). Foram coletados dados do Departamento de Informática do SUS (DATASUS) para identificar os principais determinantes das taxas de difusão das inovações tecnológicas em saúde no Brasil, especificamente em relação às inovações farmacêuticas incorporadas pelo Componente Especializado da Assistência Farmacêutica (CEAF) no SUS. No DATASUS, foram recuperados dados relativos a pacientes que haviam utilizado um dos medicamentos incorporados pelo CEAF pelo menos três anos antes do início do estudo (2015) para o tratamento de cada doença especificada. Assim, foram analisadaos dados de pacientes que utilizaram 10 diferentes medicamentos no presente estudo. Os resultados do modelo de regressão beta inflacionado demonstraram maior influência sobre taxas de difusão das inovações farmacêuticas em decorrência de: número de concorrentes farmacêuticos disponíveis no CEAF para tratamento da mesma doença (negativo); medicamentos utilizados em combinação com outros medicamentos (positivo) e medicamentos inovadores dentro do SUS (positivo). São necessários mais estudos sobre as taxas de difusão das inovações tecnológicas em saúde, incluindo uma gama maior de doenças e de medicamentos, potenciais fatores de confusão e outras variáveis que possam influenciar as taxas de adoção de inovações tecnológicas pelos diferentes sistemas de saúde.

Difusão de Inovação; Avaliação da Tecnologia Biomédica; Avaliação em Saúde

\section{Resumen}

Un análisis de impacto presupuestario requiere un conjunto de información esencial sobre innovación en tecnología de la salud, incluyendo tasas esperadas de incorporación. Existe una falta de estudios que investiguen tendencias, magnitud de los efectos presupuestarios, y determinantes de las tasas de difusión para innovaciones en tecnología de salud en todo el mundo durante las últimas décadas. El presente estudio propone una evaluación piloto sobre los principales determinantes que influencian las tasas de difusión de las innovaciones farmacéuticas dentro del Sistema Único de Salud brasileño (SUS). Los datos provienen del Departamento de Información del SUS (DATASUS) y fueron recopilados para establecer los principales determinantes de las tasas de difusión de innovaciones en tecnología de la salud en Brasil, refiriéndose a las innovaciones farmacéuticas incorporadas en el Programa brasileño para Servicios Farmacéuticos Especializados (CEAF) en el SUS. La información fue rescatada del DATASUS relativa a pacientes que habian usado una de las medicines incorporadas al CEAF al menos 3 años antes del comienzo del estudio (2015) para tratamiento de cada condición de salud disponible. Así, fueron analizados datos de pacientes que usaron 10 medicamentos diferentes. Los resultados del modelo de regresión beta aumentada mostraron una influencia más alta en las tasas de difusión de las innovaciones farmacéuticas debido a: número de competidores para el tratamiento de la misma enfermedad disponible en el CEAF (negativo); medicamentos usados en combinación con otra medicación (positivo); $y$ medicina innovadora en el SUS (positivo). Se requiere más investigación adicional sobre las tasas de difusión en tecnología de la salud, incluyendo un enfoque más amplio de las enfermedades y su medicación, potenciales factores de confusión y otras variables que quizás influencien las tasas de incorporación a los diferentes sistemas de salud.

Difusión de Innovaciones; Evaluación de la Tecnología Biomédica; Evaluación en Salud
Submitted on 16/Apr/2016

Final version resubmitted on 28/Jun/2016 Approved on 20/Jul/2016 
Schneiders RE, Ronsoni RM, Sarti FM, Nita ME, Bastos EA, Zimmermann IR, Ferreira FF. Factors associated with the diffusion rate of innovations: a pilot study from the perspective of the Brazilian Unified National Health System. Cad Saúde Pública 2016; 32(9):e00067516. doi:org/10.1590/0102-311XER011116
The journal has been informed about some errors in the paper. The corrections are follows:

A revista foi informada sobre alguns erros no artigo. As correções seguem abaixo:

La revista fue informada sobre algunos errores en el artículo. Siguen las correcciones:

- Where the text read:

Table 1

Selected pharmaceutical innovations incorporated in the Brazilian Program for Specialized Pharmaceutical Services (CEAF). Brazil, 2015.

\begin{tabular}{|c|c|c|c|c|c|c|c|}
\hline \multirow[t]{3}{*}{ Medicine } & \multirow[t]{3}{*}{$\begin{array}{l}\text { Incorporation } \\
\text { date }\end{array}$} & \multirow[t]{3}{*}{ Indication } & \multirow[t]{3}{*}{$\begin{array}{l}\text { Other treatments } \\
\text { available at CEAF }\end{array}$} & \multicolumn{4}{|c|}{$\begin{array}{l}\text { Proportion of patients using innovative medicine * } \\
\text { [month/period] }(\%)\end{array}$} \\
\hline & & & & 1 st & $12^{\text {th }}$ & 24th & 36th \\
\hline & & & & $t=0$ & $t=4$ & $t=8$ & $t=12$ \\
\hline Cyclophosphamide & Oct/2008 & $\begin{array}{l}\text { Acquired chronic } \\
\text { pure red cell aplasia }\end{array}$ & $\begin{array}{c}\text { Azathioprine, Cyclo- } \\
\text { sporine, Immuno- } \\
\text { glubulin }\end{array}$ & 0.0 & & & \\
\hline Deferasirox & Oct/2008 & $\begin{array}{l}\text { Chronic iron over- } \\
\text { load }\end{array}$ & $\begin{array}{l}\text { Deferiprone, Defer- } \\
\text { oxamine }\end{array}$ & 0.0 & 67.5 & 76.9 & 79.6 \\
\hline Everolimus & Oct/2008 & Kidney transplant & $\begin{array}{c}\text { Azathioprine, Cy- } \\
\text { closporine, Methyl- } \\
\text { prednisolone, Myco- } \\
\text { phenolate mofetil, } \\
\text { Mycophenolate } \\
\text { sodium, Sirolimus, } \\
\text { Tacrolimus }\end{array}$ & 0.0 & 0.1 & 1.2 & 1.9 \\
\hline Galantamine & Oct/2008 & Alzheimer's disease & $\begin{array}{l}\text { Donepezil, Rivastig- } \\
\text { mine }\end{array}$ & 7.4 & 11.7 & 15.5 & 16.8 \\
\hline $\begin{array}{l}\text { Aluminium hydrox- } \\
\text { ide }\end{array}$ & Mar/2010 & $\begin{array}{l}\text { Hyperphosphatemia } \\
\text { in chronic kidney } \\
\text { insufficiency }\end{array}$ & Calcitriol, Sevelamer & 0.0 & 0.0 & 0.0 & 0.0 \\
\hline Clobazam & Mar/2010 & Epilepsy & $\begin{array}{c}\text { Ethosuximide, Gaba- } \\
\text { pentin, Lamotrigine, } \\
\text { Primidone, Topira- } \\
\text { mate, Vigabatrin }\end{array}$ & 0.0 & 5.1 & 3.7 & 4.5 \\
\hline Entecavir & Dec/2009 & Hepatitis B & $\begin{array}{c}\text { Adefovir, Interferon- } \\
\text { alpha, Lamivudine, } \\
\text { Tenofovir }\end{array}$ & 0.0 & 21.8 & 30.0 & \\
\hline Sildenafil & Mar/2010 & $\begin{array}{l}\text { Pulmonary arterial } \\
\text { hypertension }\end{array}$ & Iloprost & 99.0 & 99.9 & 99.9 & 100.0 \\
\hline Natalizumab & Mar/2010 & Multiple sclerosis & $\begin{array}{l}\text { Azathioprine, Glat- } \\
\text { iramer, Interferon- } \\
\text { beta }\end{array}$ & 0.0 & 2.0 & 5.2 & 6.6 \\
\hline Pyridostigmine & Mar/2010 & Myasthenia gravis & $\begin{array}{c}\text { Azathioprione, Cy- } \\
\text { closporine, Immuno- } \\
\text { globulin }\end{array}$ & 0.0 & 27.2 & 32.8 & 36.6 \\
\hline
\end{tabular}

* Percentage in relation to the total number of patients treated for the disease at the CEAF for the same use.

Source: prepared by the authors, based on synthesis from Brazilian Health Informatics Department (DATASUS). 
- It should read:

Table 1

Selected pharmaceutical innovations incorporated in the Brazilian Program for Specialized Pharmaceutical Services (CEAF). Brazil, 2015.

\begin{tabular}{|c|c|c|c|c|c|c|c|}
\hline \multirow[t]{3}{*}{ Medicine } & \multirow[t]{3}{*}{$\begin{array}{l}\text { Incorporation } \\
\text { date }\end{array}$} & \multirow[t]{3}{*}{ Indication } & \multirow[t]{3}{*}{$\begin{array}{l}\text { Other treatments } \\
\text { available at CEAF }\end{array}$} & \multicolumn{4}{|c|}{$\begin{array}{l}\text { Proportion of patients using innovative medicine * } \\
\text { [month/period] (\%) }\end{array}$} \\
\hline & & & & 1 st & $12^{\text {th }}$ & $24^{\text {th }}$ & 36th \\
\hline & & & & $t=0$ & $t=4$ & $t=8$ & $t=12$ \\
\hline Cyclophosphamide & Oct/2008 & $\begin{array}{l}\text { Acquired chronic } \\
\text { pure red cell aplasia }\end{array}$ & $\begin{array}{l}\text { Azathioprine, } \\
\text { Cyclosporine, } \\
\text { Immunoglubulin }\end{array}$ & 0.0 & 0.1 & 1.3 & 9.1 \\
\hline Deferasirox & Oct/2008 & $\begin{array}{l}\text { Chronic iron } \\
\text { overload }\end{array}$ & $\begin{array}{l}\text { Deferiprone, } \\
\text { Deferoxamine }\end{array}$ & 0.0 & 67.5 & 76.9 & 79.6 \\
\hline Everolimus & Oct/2008 & Kidney transplant & $\begin{array}{c}\text { Azathioprine, } \\
\text { Cyclosporine, } \\
\text { Methylprednisolone, } \\
\text { Mycophenolate } \\
\text { mofetil, } \\
\text { Mycophenolate } \\
\text { sodium, Sirolimus, } \\
\text { Tacrolimus }\end{array}$ & 0.0 & 0.1 & 1.2 & 1.9 \\
\hline Galantamine & Oct/2008 & Alzheimer's disease & $\begin{array}{l}\text { Donepezil, } \\
\text { Rivastigmine }\end{array}$ & 7.4 & 11.7 & 15.5 & 16.8 \\
\hline $\begin{array}{l}\text { Aluminium } \\
\text { hydroxide }\end{array}$ & Mar/2010 & $\begin{array}{l}\text { Hyperphosphatemia } \\
\text { in chronic kidney } \\
\text { insufficiency }\end{array}$ & Calcitriol, Sevelamer & 0.0 & 0.0 & 0.0 & 0.0 \\
\hline Clobazam & Mar/2010 & Epilepsy & $\begin{array}{l}\text { Ethosuximide, } \\
\text { Gabapentin, } \\
\text { Lamotrigine, } \\
\text { Primidone, } \\
\text { Topiramate, } \\
\text { Vigabatrin }\end{array}$ & 0.0 & 5.1 & 3.7 & 4.5 \\
\hline Entecavir & $\mathrm{Dec} / 2009$ & Hepatitis B & $\begin{array}{c}\text { Adefovir, Interferon- } \\
\text { alpha, Lamivudine, } \\
\text { Tenofovir }\end{array}$ & 0.0 & 21.8 & 30.1 & 33.9 \\
\hline Sildenafil & Mar/2010 & $\begin{array}{l}\text { Pulmonary arterial } \\
\text { hypertension }\end{array}$ & Iloprost & 99.0 & 99.9 & 99.9 & 100.0 \\
\hline Natalizumab & Mar/2010 & Multiple sclerosis & $\begin{array}{l}\text { Azathioprine, } \\
\text { Glatiramer, } \\
\text { Interferon-beta }\end{array}$ & 0.0 & 2.0 & 5.2 & 6.6 \\
\hline Pyridostigmine & Mar/2010 & Myasthenia gravis & $\begin{array}{l}\text { Azathioprione, } \\
\text { Cyclosporine, } \\
\text { Immunoglobulin }\end{array}$ & 0.0 & 27.2 & 32.8 & 36.6 \\
\hline
\end{tabular}

* Percentage in relation to the total number of patients treated for the disease at the CEAF for the same use.

Source: prepared by the authors, based on synthesis from Brazilian Health Informatics Department (DATASUS). 
Description and characterization of categories of independent variables for analysis of diffusion rate of pharmaceutical innovations in the Brazilian Unified National Health System (SUS). Brazil, 2015.

\section{Category of variable \\ 1. Other treatments already available at the CEAF \\ Description Analyzes the influence of preexistence of other medication available for treatment of the same disease at CEAF, which may facilitate access to pharmaceutical innovations due to previous knowl- edge of physicians and patients. \\ Method Search in CEAF ordinances to identify other medication associated with ICD-10 correspondent to the specific disease targeted by the pharmaceutical innovation.}

\section{Number of competitors for treatment of the same disease}

Description Identifies the amount of competitor medications for the same line of treatment of the disease, influencing the probability of pharmaceutical innovation adoption.

Method Analysis of the first clinical PCDT available for the targeted disease. If no competitor medications are mentioned, the variable value was zero. Otherwise, the number of active principles competing for treatment of the same disease was computed.

\section{Line of treatment}

Description Analyzes the influence of the line of treatment on diffusion rates, since medication in the last line of treatment, theoretically, should be prescribed to a smaller number of patients.

Method

Analysis of the first PCDT available for the targeted disease, in order to identify changes in line of treatment using another health technology (pharmaceutical or other) in case of refractoriness, fail or intolerance to standard treatment. If it was not possible to establish a line of treatment, the term "non-defined" was attributed.

\section{Medicine used in combination with other medication}

Description Verifies the influence of need to adopt a combined use of medication, due to potential difficulties to access other medicines prescribed.

Method Analysis of the first PCDT available for the targeted disease, in order to identify indication of use in association with other medicines.

\section{Innovation within the SUS}

Description Analyzes the influence of incremental benefits of the pharmaceutical innovation in comparison to other types of treatment of the disease.

Method Due to absence of specific definition regarding the concept of innovation in health care, the following premises were adopted:

Medication for treatment of diseases not yet available at SUS;

Medication for treatment of diseases already available that:

Represents new line of treatment of the disease; or

Presents improved efficacy in relation to other medication already available, based on search of evidences published in meta-analysis or direct comparison 20,21.

Other medications competing in the same line of treatment and in the same pharmacological category were not considered innovative.

6. Time gap between from incorporation and clinical protocol publication (months)

Description Analyzes the influence of PCDT in diffusion rates, due to definition of prescription and utilization criteria.

Method Identification of the publication date of PCDT. If the PCDT was published prior to the medication incorporation, the variable value was zero.

\section{Treatment for infectious diseases}

Description Analyzes the influence of type of disease in diffusion rates of pharmaceutical innovations, considering that infectious diseases have limited time for treatment in comparison to other types of diseases.

Method

Assessment of characteristics of the targeted diseases, according to description in PCDT.

Value

Binary variable

(Yes, No)

Discrete variable

(Count)

Binary variable for each line of treatment

(1st line, 2nd line, 3rd line, or

NA)

Binary variable (Yes, No)

Binary variable (Yes, No)
Discrete variable

(Count)

Binary variable

(Yes, No)

(continues) 


\section{Lag period after incorporation of the medicine (in trimesters)}

Description Information used to estimate the diffusion rates over time (up to three years after incorporation).

Method Assignment of ordinal category corresponding to the number of trimesters after incorporation.

\section{Area of specialty in medicine}

Description Analyzes the influence of the area of medical specialty of the disease on diffusion rates of pharmaceutical innovations.

Method

Analysis of the PCDT for the targeted disease, in order to determine the area of medical specialty for treatment of the disease. Each disease was categorized in only one specialist area, if more than one area was indicated; the most representative specialist area was adopted.

\section{Medicine with patent (monopoly)}

Description Analyzes the influence of the presence or absence of generic or similar drugs at the moment of incorporation, which presupposes the absence or presence of patent, respectively.

Method Search in the price list of the Chamber for Regulation of the Pharmaceutical Market, in order to identify generic or similar drugs in Brazil.

\section{Annual cost of drug therapy per patient}

Description

Analyzes the interference of drug therapy costs per patient in the diffusion rate and potential impacts of reduction in prices due to scale in production, considering that overall budget impact may influence the access to medication within the SUS

Method

Estimation of annual costs for standard treatment (in log), considering recommended dosage of the medication in the PCDT for the targeted disease, at the period of pharmaceutical innovation incorporation within the SUS. A standard patient profile weighting $70 \mathrm{~kg}$ was adopted, in case of dosage per body weight. The annual costs were based on the amount of medication for annual treatment and the PMC (18\%) from the Chamber for Regulation of the Pharmaceutical Market (2014).

\section{Higher price in comparison to pharmaceutical competitors}

Description Analyzes the influence of variations in price on the diffusion rate, in comparison with other technologies for drug therapy of the same disease already available at the SUS.

Method

Comparison of the variable "annual cost of drug therapy per patient" in relation to the annual costs estimated for drug therapy of the targeted disease using other medication available within SUS. The annual costs were based on the amount of medication for annual treatment and the PMC (18\%) from the Chamber for Regulation of the Pharmaceutical Market (2014). If there are no other

therapeutic options for treatment of the disease, the variable value was "non applicable".

\section{Public management level responsible for acquisition of medication}

Description Assesses the impact of diverse patterns of acquisition of medication for CEAF (federal, and/or state level acquisition) on diffusion rates.

Method

Identification of the public management level responsible for acquisition of the medication, through search in Ministry of Health ordinances that established the Component of Medications with Exceptional Dispensation (Ordinance GM/MS 2,577/2006), the CEAF (Ordinance GM/MS

$2,981 / 2009)$, and other ordinances published for alteration or revocation of the previous ordinances and its annexes. Changes in responsibility during the period analyzed were categorized as "both".

\section{State of residence of patient}

Description

Method

SUS or in execution of CEAF, and its influence on diffusion rates.

Extraction of data regarding patients' state of residence from SUS databases,
Discrete variable

(Count)

Binary variable for each area of medical specialty

(Cardiology, Hematology, Infectious Disease, Rheumatology,

Gastroenterology, Nephrology, Neurology)

Binary variable (Yes, No)

Continuous variable ( $\log R \$)$

Binary variable

(Yes, No, NA)

Dummy variable for each government level

(Ministry of Health, State Secretary of Health, or both)

Binary variable for each Brazilian state

described in Methods.

(continues) 


\section{Region of residence of patient}

Description

Verifies differences

by SUS or in execution of CEAF, and its influence on diffusion rates.

Method Extraction of data regarding patients' region of residence from SUS databases, described in Meth-

\section{Long-term use medication}

Description

Analyzes the influence of period recommended for treatment on diffusion rate, considering that continuous-use medication usually presents lower adherence from patients.

Method Analysis of general recommendations regarding the period recommended for treatment using the medication in the PCDT for the targeted disease, at the period of pharmaceutical innovation incorporation within SUS. Long-term use medication was considered to be indicated for utilization during periods longer than one year of treatment. In the case of pharmaceutical innovations without published PCDT at the moment of incorporation, information contained in recent PCDT were adopted.

\section{Improvement in route of administration}

Analyzes the impact of advantages in dosage scheme or route of administration of the pharmaceutical innovation in comparison to other medications already available for treatment of the same disease at CEAF.

Method Analysis of recommended dosage of the pharmaceutical innovation in comparison to other medication available, considering information of dosage per week or ease in route of administration. Advantages in route of administration were based on the following hierarchy: oral > subcutaneous or intradermic > intramuscular > intravenous (with the first options considered to be preferable to the latter ones).

Binary variable: variable assuming values 0 or 1, according to the characteristics attributable to the case in analysis, indicating the effect of the characteristic described on the rate of adoption; CEAF: Brazilian Program for Specialized Pharmaceutical Services; ICD-10: 10th revision of the International Classification of Diseases; NA: non-applicable; PCDT: clinical protocol and therapeutic guideline; PMC: maximum price for consumers. Source: prepared by the authors, based on synthesis of documental research at the Brazilian Ministry of Health. 
Description and characterization of categories of independent variables for analysis of diffusion rate of pharmaceutical innovations in the Brazilian Unified National Health System (SUS). Brazil, 2015.

\begin{tabular}{lll}
\hline Category of variable & Value
\end{tabular}

\section{Other treatments already available at the CEAF}

Description Analyzes the influence of preexistence of other medication available for treatment of the same disease at CEAF, which may facilitate access to pharmaceutical innovations due to previous knowledge of physicians and patients.

Method Search in CEAF ordinances to identify other medication associated with ICD-10 correspondent to the specific disease targeted by the pharmaceutical innovation.

\section{Number of competitors for treatment of the same disease}

Description Identifies the amount of competitor medications for the same line of treatment of the disease, influencing the probability of pharmaceutical innovation adoption.

Method Analysis of the first clinical PCDT available for the targeted disease. If no competitor medications are mentioned, the variable value was zero. Otherwise, the number of active principles competing for treatment of the same disease was computed.

\section{Line of treatment}

Description Analyzes the influence of the line of treatment on diffusion rates, since medication in the last line of treatment, theoretically, should be prescribed to a smaller number of patients.

Method

Analysis of the first PCDT available for the targeted disease, in order to identify changes in line of treatment using another health technology (pharmaceutical or other) in case of refractoriness, fail or intolerance to standard treatment. If it was not possible to establish a line of treatment, the term "non-defined" was attributed.

\section{Medicine used in combination with other medication}

Description Verifies the influence of need to adopt a combined use of medication, due to potential difficulties to access other medicines prescribed.

Method

Analysis of the first PCDT available for the targeted disease, in order to identify indication of use in association with other medicines.

\section{Innovation within the SUS}

Description Analyzes the influence of incremental benefits of the pharmaceutical innovation in comparison to other types of treatment of the disease.

Method

Due to absence of specific definition regarding the concept of innovation in health care, the following premises were adopted:

- Medication for treatment of diseases not yet available at SUS;

- Medication for treatment of diseases already available that:

A. Represents new line of treatment of the disease; or

B. Presents improved efficacy in relation to other medication already available, based on search of evidences published in meta-analysis or direct comparison 20,21.

Other medications competing in the same line of treatment and in the same pharmacological category were not considered innovative.

\section{Time gap between from incorporation and clinical protocol publication (months)}

Description

Analyzes the influence of PCDT in diffusion rates, due to definition

of prescription and utilization criteria.

Method Identification of the publication date of PCDT. If the PCDT was published prior to the medication incorporation, the variable value was zero.

\section{Treatment for infectious diseases}

Description

Analyzes the influence of type of disease in diffusion rates of pharmaceutical innovations, considering that infectious diseases have limited time for treatment in comparison to other types of diseases.

Method
Binary variable

(Yes, No)

Discrete variable

(Count)

Binary variable for each line of treatment

(1st line, 2nd line, 3rd line, or NA)

Binary variable (Yes, No)

Binary variable (Yes, No)
Discrete variable

(Count)

Binary variable

(Yes, No)

(continues) 


\section{Lag period after incorporation of the medicine (in trimesters)}

Description Information used to estimate the diffusion rates over time (up to three years after incorporation).

Method Assignment of ordinal category corresponding to the number of trimesters after incorporation.

\section{Area of specialty in medicine}

Description

Analyzes the influence of the area of medical specialty of the disease on diffusion rates of pharmaceutical innovations.

Method

Analysis of the PCDT for the targeted disease, in order to determine the area of medical specialty for treatment of the disease. Each disease was categorized in only one specialist area, if more than one area was indicated; the most representative specialist area was adopted.

10. Medicine with patent (monopoly)

Description

Analyzes the influence of the presence or absence of generic or similar drugs at the moment of incorporation, which presupposes the absence or presence of patent, respectively.

Method Search in the price list of the Chamber for Regulation of the Pharmaceutical Market, in order to identify generic or similar drugs in Brazil.

\section{Annual cost of drug therapy per patient}

Description

Analyzes the interference of drug therapy costs per patient in the diffusion rate and potential impacts of reduction in prices due to scale in production, considering that overall budget impact may influence the access to medication within the SUS.

Method

Estimation of annual costs for standard treatment (in log), considering recommended dosage of the medication in the PCDT for the targeted disease, at the period of pharmaceutical innovation incorporation within the SUS. A standard patient profile weighting $70 \mathrm{~kg}$ was adopted, in case of dosage per body weight.

The annual costs were based on the amount of medication for annual treatment and the PMC (18\%) from the Chamber for Regulation of the Pharmaceutical Market (2014).

\section{Higher price in comparison to pharmaceutical competitors}

Description

Analyzes the influence of variations in price on the diffusion rate, in comparison with other technologies for drug therapy of the same disease already available at the SUS

Method Comparison of the variable "annual cost of drug therapy per patient" in relation to the annual costs estimated for drug therapy of the targeted disease using other medication available within SUS. The annual costs were based on the amount of medication for annual treatment and the PMC (18\%) from the Chamber for Regulation of the Pharmaceutical Market (2014). If there are no other therapeutic options for treatment of the disease, the variable value was "non applicable".

13. Public management level responsible for acquisition of medication

Description Assesses the impact of diverse patterns of acquisition of medication for CEAF (federal, and/or state level acquisition) on diffusion rates.

Method

Identification of the public management level responsible for acquisition of the medication, through search in Ministry of Health ordinances that established the Component of Medications with Exceptional Dispensation (Ordinance GM/MS 2,577/2006), the CEAF (Ordinance GM/MS 2,981/2009), and other ordinances published for alteration or revocation of the previous ordinances and its annexes. Changes in responsibility during the period analyzed were categorized as "both".

\section{State of residence of patient}

Description Verifies differences among states of residence of patients in the access of medication provided by SUS or in execution of CEAF, and its influence on diffusion rates.

Method
Extraction of data regarding patients' state of residence from SUS databases, described in Methods.
Discrete variable

(Count)

Binary variable for each area of medical specialty

(Cardiology, Hematology, Infectious Disease,

Rheumatology,

Gastroenterology, Nephrology،

Neurology)

Binary variable (Yes, No)

Continuous variable ( $\log R \$)$

Binary variable

(Yes, No, NA)

Dummy variable for each government level

(Ministry of Health, State

Secretary of Health, or both)

Binary variable for each Brazilian state

(continues) 


\section{Region of residence of patient}

Description

Verifies differences among regions of residence of patients in the access of medication provided by SUS or in execution of CEAF, and its influence on diffusion rates.

Method Extraction of data regarding patients' region of residence from SUS databases, described in Methods.

\section{Long-term use medication}

Description

Analyzes the influence of period recommended for treatment on diffusion rate, considering that continuous-use medication usually presents lower adherence from patients.

Method Analysis of general recommendations regarding the period recommended for treatment using the medication in the PCDT for the targeted disease, at the period of pharmaceutical innovation incorporation within SUS. Long-term use medication was considered to be indicated for utilization during periods longer than one year of treatment. In the case of pharmaceutical innovations without published PCDT at the moment of incorporation, information contained in recent PCDT were adopted.

17. Improvement in route of administration

Description

Analyzes the impact of advantages in dosage scheme or route of administration of the pharmaceutical innovation in comparison to other medications already available for treatment

of the same disease at CEAF.

Method

Analysis of recommended dosage of the pharmaceutical innovation in comparison to other medication available, considering information of dosage per week or ease in route of administration. Advantages in route of administration were based on the following hierarchy: oral > subcutaneous or intradermic > intramuscular > intravenous (with the first options considered to be preferable to the latter ones).
Binary variable for each Brazilian region

Binary variable (Yes, No)

Binary variable

(Yes, No)

Binary variable: variable assuming values 0 or 1, according to the characteristics attributable to the case in analysis, indicating the effect of the characteristic described on the rate of adoption; CEAF: Brazilian Program for Specialized Pharmaceutical Services; ICD-10: 10th revision of the International Classification of Diseases; NA: non-applicable; PCDT: clinical protocol and therapeutic guideline; PMC: maximum price for consumers. Source: prepared by the authors, based on synthesis of documental research at the Brazilian Ministry of Health. 